\title{
LIQUIDITY RISK MANAGEMENT: PRACTICE AMONG CROATIAN FIRMS ${ }^{4}$
}

\begin{abstract}
The main purpose of this paper is to explore the practice of liquidity risk management of Croatian business entities. The analysis is based on a survey of 62 business entities in Croatia. The authors investigate the existence of risk management and liquidity risk management measures among the surveyed business entities. The respondents' knowledge of management, their use of indicators and methods for the management of liquidity risk, in addition to the cited reasons for implementation of liquidity risk measures were also subject to examination. Furthermore, the authors investigate the importance of liquidity management in business. The analysis reveals that Croatian business entities have neither sufficient knowledge regarding the majority of financial indicators, nor they tend to use liquidity management plans. Consequently, the survey's findings indicate that the overall level of financial knowledge of Croatian managers is inadequate. This can, thus, be identified as one of the reasons for the traditionally high number of illiquid business entities in the market. Finally, this paper provides academia and policymakers with new revelations concerning the management of liquidity risk among business entities in Croatia.
\end{abstract}

Key words: liquidity, finance, risk management, Croatia, survey

\section{INTRODUCTION}

Various risks arise during the running of day-to-day business and operations activities in companies. Financial risks are among the most frequent ones; since they emerge in almost every company, they can be considered both a universal and a global phenomenon. Many financial risks arise from the simple act of running a business. Hence, one of the most frequent financial risks is the liquidity risk. It is difficult to completely avoid it as it is connected to the optimal short-term and long-term level of company assets. "Liquidity has always been a specific priority area for financial managers. Liquidity-related risks can often lead to deterioration of the financial situation and even bankruptcy"(Raykov, 2017:136). Therefore, it is necessary to manage the liquidity risk to mitigate

PhD, Assistant Professor, Faculty of Tourism and Hospitality Management, Primorska 42, 51410 Opatija, Croatia. E-mail: gorank@fthm.hr

2 PhD, Assistant Professor, Business school PAR, Trg Riječke rezolucije 4, 51000 Rijeka, Croatia.

E-mail: bisera.karanovic@par.hr

3 M Econ, Student, Faculty of Tourism and Hospitality Management, Primorska 42, 51410 Opatija, Croatia. E-mail:martina.gnjidic@hotmail.com

4 Received:13 November 2017; Accepted: 15 January 2018 
its negative effects on the business. "There is a common knowledge that even the most profitable company may go bankrupt if it does not manage its liquidity in a proper way"(Błach et al., 2014: 210). To maintain optimal liquidity of a business entity, specific business management activities are required. In the liquidity management process, the management needs to view comprehensively and deeply the financial condition of the business entity in question. With regards to liquidity, this implies monitoring the asset structure and sources of asset financing, the relationship between short-term and long-term asset financing sources, as well as the key activities that affect the speed of asset circulation in the business process. "Liquidity management maintaining the current assets and current liabilities balance on a proper level is an important condition for improving performance of the company and its value enhancement" (Hiadlovský et al., 2016: 802). In his study, Crockett wrote that liquidity is easier to recognize than to define (2008: 14). "Liquidity is a complex concept defined by multiple factors, which are used in different ways. Basically, the term liquidity means how easy we can generate cash from assets. Cash may be generated either by using creditworthiness to obtain external funds, or by the sale of owned assets in the market"(Tibor and Fenyves, 2011: 531). According to Dencic-Mihajlov et al., liquidity is interpreted as the ability of a company to pay outstanding liabilities as they come due. It is also true that both the asset structure and the capital structure are important determinants of liquidity"(2014: 91). Liquidity is a complex concept and cannot be described by using just one indicator. Due to its complexity, liquidity can be explored in various contexts. Some studies explore the optimal level of the volume of current assets (Kumar Manjhi 2012; Ortiz-Molina and Phillips 2014), while others focus on the relationship between the volume of current assets and the company's profitability (Mamic Sacer et.al, 2013: 15-35). "The most common indicators of measuring liquidity are the current ratio and the quick ratio (also referred to as the acid-test ratio). They are static measures of liquidity, based on forced liquidation of assets, and do not measure the ongoing ability of a firm to go back to cash"(Lancaster and Stevens, 1998: 27-38).

This paper examines the existence of organized risk management of business and financial risks, the knowledge and use of liquidity risk indicators and methods in business operations, as well as the assessment of business subjects about the importance of liquidity risk management in business. The research in this paper includes business entities regardless of the type of business, except for credit and financial institutions (insurance companies), but not all entities that deal with financial activities. Many studies have shown that liquidity is important both for businesses and investors. First, it is a source of risk (Acharya and Pendersen, 2005: 375-410); second, illiquid firms must deliver higher returns; and third, liquidity is an important determinant of the cost of capital (Amihud and Mendelson, 1986: 223-249). Finally, liquidity risk is an important risk component (Stange and Kaserer, 2011; Lei and Lai, 2007). A very important factor influencing liquidity is the type of business that a business entity is dealing with (Mamic Sacer et.al, 2013:15-35). The activity of a business entity is a very important factor influencing liquidity; however, the structure of assets and liabilities is just as important. The structure of assets and liabilities is closely related to the size of a business entity (Sarlija et.al 2009; Jezovita 2015).

The problem with illiquidity in Croatia is not a new one. By the mid 1990's this was one of the most significant issues of the economy overall. The liquidity crisis escalated by the end of the 1990's 
and this microeconomic problem - driven by improper macroeconomic politics and transition as a historical background - evolved to the point of becoming one of the biggest problems for the domestic economy. In his liquidity analysis of companies situated in Split-Dalmatia County, Soric (2004) concluded that liquidity ratios are one of the first indicators that signal the existence of disturbances in the economy of Split-Dalmatia County. Cizmesija, Kurnoga and Zivadinovic stated that in 1999 this area accounted for roughly 20\% of GDP (2012: 281). Illiquidity of these proportions has had impact on the costs of doing business in the country as the additional source of growth of business expenses (Nikic, 2004). In the first half of 2000's the problem was reduced to a tolerable extent. Even in those years of expansive macroeconomic politics, and in times of sufficient money supply, according to the survey conducted by Dumicic et. al. (2006: 25), Croatian managers' greatest fear was that of liquidity risk. Again, the problem escalated under the impact of the Global Financial Crisis. In Croatia, the measure of illiquidity on a microeconomic level is the number of companies with "frozen accounts". The frozen account is a state in which companies default on the full payment, i.e. companies are not able to service the obligations that have come due. The following table presents the number of companies with frozen accounts and the amount of defaults on the full payment 2011-2017. It bears emphasis that Croatia has emerged from the recession caused by the Global Financial Crisis as recently as 2015.

Table 1. Number of companies with frozen accounts and amount of defaults on the full payment

\begin{tabular}{|c|c|c|c|c|c|c|}
\hline \multirow{2}{*}{$\begin{array}{c}\text { Frozen } \\
\text { account } \\
\text { (in days) }\end{array}$} & \multicolumn{2}{|c|}{31 October 2011 } & \multicolumn{2}{c|}{31 October 2012 } & \multicolumn{2}{c|}{31 October 2013 } \\
\cline { 2 - 7 } & No & HRK & No & HRK & No & HRK \\
\hline Up to 30 & 1,329 & $1,099,473$ & 2,436 & 522,934 & 6,334 & 802,537 \\
\hline $31-60$ & 773 & 427,088 & 1,859 & 742,327 & 4,359 & 359,881 \\
\hline $61-180$ & 3,004 & $2,028,498$ & 4,934 & $2,541,574$ & 4,825 & $1,889,202$ \\
\hline $181-360$ & 3,051 & $2,375,241$ & 7,066 & $4,131,430$ & 6,364 & $1,992,371$ \\
\hline over 360 & 27,454 & $27,753,632$ & 56,359 & $36,600,117$ & 40,066 & $28,971,319$ \\
\hline$\Sigma$ & 35,611 & $33,683,932$ & 72,654 & $44,538,382$ & 61,948 & 802,537 \\
\hline
\end{tabular}

\begin{tabular}{|c|c|c|c|c|c|c|c|c|}
\hline \multirow{2}{*}{$\begin{array}{l}\text { Frozen } \\
\text { account } \\
\text { (in days) }\end{array}$} & \multicolumn{2}{|c|}{30 November 2014} & \multicolumn{2}{|c|}{31 October 2015} & \multicolumn{2}{|c|}{31 October 2016} & \multicolumn{2}{|c|}{31 October 2017} \\
\hline & No & HRK & No & HRK & No & HRK & No & HRK \\
\hline Up to 30 & 1,470 & 400,874 & 1,071 & 247,005 & 1,400 & 540,305 & 1,247 & 345,765 \\
\hline $31-60$ & 1,091 & 160,978 & 783 & 631,131 & 758 & 271,602 & 598 & 343,538 \\
\hline $61-180$ & 2,292 & $1,219,413$ & 1,750 & 999,832 & 1,982 & 828,680 & 1,908 & 632,124 \\
\hline $181-360$ & 3,390 & $1,344,928$ & 2,732 & $1,387,930$ & 2,539 & $1,836,043$ & 2,025 & $1,373,382$ \\
\hline over 360 & 16,966 & $19,136,762$ & 14,543 & $15,286,215$ & 5,918 & $8,599,695$ & 4,094 & $6,239,438$ \\
\hline$\Sigma$ & 25,209 & $22,262,954$ & 20,879 & $18,552,113$ & 12,597 & $12,076,325$ & 9,872 & $8,934,246$ \\
\hline
\end{tabular}

Source: FINA (www.fina.hr) edited by authors 
It is evident from the table that both the recession and the crisis had a huge impact on the number of illiquid companies in Croatia. In addition, it may be concluded that with the economy recovered, the number of illiquid companies was reduced. The latest numbers on illiquidity are not satisfactory, however. The majority of 9,448 companies in 2017 (FINA 2017) still have frozen accounts with the total amount of defaults on the full payment amounting to 8,642 billion HRK (approximately 1,153 billion EUR).

The purpose of this paper is to examine the impact of liquidity risk on businesses in the Republic of Croatia. This paper has three goals: to explore the existence of organized risk management of business and financial risks, to inspect the knowledge and use of indicators and methods of liquidity risk management in business, and to examine business entities assessment of the importance of risk management for business liquidity.

The remainder of this paper is arranged as follows: Section 2 gives an overview of current liquidity literature. Section 3 provides a summary of the liquidity risk management of business entities in the Republic of Croatia with subsection 3.1. covering knowledge and use of indicators and methods of liquidity risk management in business entities of the Republic of Croatia along with subsection which goes into valuation of liquidity risk in businesses in the Republic of Croatia. Finally, Section 4 concludes the whole research and provides recommendations for further analysis.

\section{LITERATURE REVIEW}

Liquidity is an important risk factor, which has motivated many authors to do research on this topic. Conversely, liquidity risk is observed by the authors both through market and asset liquidity.

Liquidity has had wide-ranging effects on financial markets (Amihud, et al., 2005: 269-364). Also, for the Central and Eastern countries Oglic Drazenovic and Kusanovic state that these economies have underdeveloped, narrow, and illiquid capital markets (2016: 759).

On the one hand, Bangia, et al., assert that liquidity risk is an important component for capturing the overall risk (1999: 1-16). On the other hand, the importance of liquidity can be observed through liquidity of assets. Morallec notes that the relevance of liquid assets depends on the way of their measurement, on the liquidation value of firm's assets or on the selling price of assets over the entire life of the firm (2001: 173-206).

Many studies connect - theoretically and empirically - the influence of liquidity on profitability. Therefore, different authors propose the idea of liquidity having a positive influence on profitability (Vieira 2010; Mihajlov 2014; Mushtaq et al. 2015; Kung'u 2017). Apart from the influence of liquidity on profitability, authors also investigate the relationship between liquidity and leverage. The studies have shown a negative relationship between debt and corporate liquidity (Kim et al. 1998; Opler et al. 1999). This type of a relationship is confirmed on a sample of US companies (Lipson and Mortal, 2009), in the case of Malaysian companies (Suhaila et al., 2008), in the case of UK companies (Ozkan, 2001), on a sample of Greek firms (Eriotis et al.,2007) and in Chinese firms, which analyzed the leverage-liquidity relationship (Liu et al., 2009). They all demonstrate that the more liquid firm is, the less leveraged it will be. Mateev et al., mention that firms keeping 
higher liquidity levels use mainly long-term debt to support their growth, while firms with a higher proportion of current liabilities in their capital structure use more short-term debt (2013, pp. 2851). The studies suggest that real asset illiquidity increases firm's overall cost of capital (Benmelech and Bergman, 2009; Ortiz-Molina and Phillip, 2014).

In empirical studies on European transition economies, the negative relationship between liquidity and leverage is confirmed in the Croatian case by Sarlija and Harc (2012). They demonstrate a negative and statistically significant relationship between liquidity and both long-term and shortterm leverage in the case of small and medium-sized Croatian companies in 2009. Also Minovic and Zivkovic (2010) demonstrate that, for the Serbian market, illiquidity and liquidity risks significantly affect price formation. The results of the research conducted by Ortiz-Molina and Phillip indicate that in addition to real asset illiquidity being a major determinant of a company's operating flexibility, it also has an economically significant impact on firm's cost of equity capital. Their results also suggest that, by increasing firms' overall cost of capital, real asset illiquidity might affect its investment decisions (Ortiz-Molina and Phillip, (2014), pp. 1-32).

As far as Croatia is concerned, several studies that investigate problem of liquidity have been identified. Sarlija, Penavin and Harc (2009) offer a model for forecasting enterprise liquidity in Croatia as a measure for risk management liquidity. Decman (2012: 464) concludes that liquidity indicator may be used as measures of the safety in Croatian economy. The previous research on this subject in the Croatian economy, carried out by Hadrovic Zekic (2013), suggested that some of the liquidity indicators are of key importance in warning about business decline. In addition, Cizmesija, Kurnoga and Bahovec (2014) explored the importance and impact of illiquidity on economy. They investigated the illiquidity and liquidity indicators as telltale signs for the production and forecasting properties of the Croatian economy.

\section{METHODOLOGY}

The study of the impact of liquidity risk on business entities in the Republic of Croatia was carried during the period from 1 February to 15 March 2017. The research included business entities regardless of their type of organization, except for credit and financial institutions that are under a legal obligation prescribed in the Credit Institutions Act to monitor their liquidity risk. For the purpose of the survey, 115 business entities were contacted, while 62 fully completed questionnaires were collected, meaning that the response rate is $53.91 \%$. The research had three goals:

1. to explore the existence of business and financial risk management,

2. to inspect the knowledge and use of indicators and methods of liquidity risk management in business entities,

3. to examine the business entities assessment of the importance of risk management in business liquidity.

For the purpose of this analysis, financial risks incorporate market risks, credit risks, liquidity risks, and operational risks (i.e. variability of interest rates, forex exchange, systematic and unsystematic 
risk, risk of inflation, commodity risk, country risk, equity risk etc.). While business risks refer to the basic viability of a business, they usually emerge from operational process of the company (i.e. human resource risks, strategic risks, management risk etc.).

The questionnaire used in this research consists of 25 questions. The structure of the questionnaire is as follows: six questions are socio-demographic; three questions examine the existence of business and financial risk management. Nine questions survey the knowledge and use of indicators and methods of liquidity risk management in a business entity, while seven questions examine the assessment of the importance of liquidity risk management in a business entity.

\section{RESULTS ON LIQUIDITY RISK OF BUSINESS ENTITIES}

The first part of the survey involved collecting basic information on business entities. From the analysis of data presented in following table, we may conclude that business entities were exclusively SPLLC ${ }^{5}$ and PLLC 6 . Of the 62 respondents, 58 responses relate to PLLC or $96.5 \%$ of the total sample.

Table 2. Type of a business entity

\begin{tabular}{|c|c|c|}
\hline Description & N & $\%$ \\
\hline Simple Private Limited Company- SPLLC & 4 & $6.5 \%$ \\
\hline Private Limited Liability Company- PLLC & 58 & $93.5 \%$ \\
\hline Public Limited Liability Company- PLLC & 0 & $0.00 \%$ \\
\hline Total & 62 & $100.00 \%$ \\
\hline
\end{tabular}

Source: authors

Apart from examining the type of business entity, other business-related information was also examined. The table below shows the primary area of the core activity of business entities.

Table 3. Primary area of the core activity of business entities

\begin{tabular}{|l|c|c|}
\hline Description & $\mathrm{N}$ & $\%$ \\
\hline Activities of providing accommodation and preparation and serving of food & 12 & $19.4 \%$ \\
\hline Wholesale and retail trade; repair of motor vehicles and motorcycles & 7 & $11.2 \%$ \\
\hline Agriculture, forestry and fishing & 4 & $6.5 \%$ \\
\hline Manufacturing & 7 & $11.2 \%$ \\
\hline Electricity, gas, steam and air conditioning supply & 4 & $6.5 \%$ \\
\hline Construction & 6 & $9.7 \%$ \\
\hline Financial activities and insurance activities & 4 & $6.5 \%$ \\
\hline Real estate business & 4 & $6.5 \%$ \\
\hline
\end{tabular}

Simple Private Limited Company

6 Private Limited Liability Company 


\begin{tabular}{|l|c|c|}
\hline Administrative and auxiliary service activities & 2 & $3,2 \%$ \\
\hline Health and social work activities & 4 & $6.5 \%$ \\
\hline Art, entertainment and recreation & 3 & $4.8 \%$ \\
\hline Transportation and storage & 1 & $1.6 \%$ \\
\hline Other service activities & 4 & $6.5 \%$ \\
\hline Other activities* & 0 & $0 \%$ \\
\hline $\begin{array}{c}\text { *Water supply; wastewater removal, waste management, and environmental remediation activities, mining and quarrying, } \\
\text { Information and communication, professional, scientific and technical activities, public administration and defense, compulsory } \\
\text { social security and education. }\end{array}$ \\
\hline
\end{tabular}

Source: authors

Most of the business entities belong to accommodation and food service activities, or $19.4 \%$. They are followed by manufacturing and wholesale and retail trade; repair of motor vehicles and motorcycles involving $11.2 \%$. All other activities occupy less than $10 \%$ of the total sample, except for water supply; wastewater removal, waste management, and environmental remediation activities, mining and quarrying, information and communication, professional, scientific and technical activities, public administration and defense, compulsory social security and education where no business entities were examined.

It should be emphasized that the conducted investigation included four entities whose core business cover financial and insurance activities. Business entities in the area of financial activities and insurance activities do not fall under the credit and insurance institutions. As stated in the introductory part, credit and insurance institutions were not investigated because they are required to monitor the liquidity risk under the Credit Institutions Act. The four entities under examination, whose core business included financial and insurance activities, are intermediaries between persons and banks, and are therefore considered as financial mediators. They must obtain a certificate from the Ministry of Finance that they have fulfilled the conditions for such a business, but have no obligation to report, and thus to monitor the liquidity risk. Of the four business entities surveyed, three deal with this activity, and one audited business entity deals with exchange transactions. Foreign exchange transactions are under the control of the Croatian National Bank they do not have to monitor liquidity risk, however, since they already have to comply with some other conditions that do not touch the liquidity risk, which is why they were not excluded from the research. Hence, we may conclude that this four audited business entities are engaged in financial activities, but are not credit institutions or insurance companies.

In addition to the basic business activity of which a business entity belongs to, the research also included the headquarters of the business entity. The most common headquarters of business entities were located in Primorje-Gorski Kotar County where 28 business entities were surveyed, or $45.1 \%$ of the total sample. This county is followed by the City of Zagreb with $22.6 \%$, Istria County $16.1 \%$, Varazdin County $8.1 \%$, Zagreb County $6.5 \%$, while the lowest number of surveyed businesses were from Split-Dalmatia County, amounting to only $1.6 \%$. According to the number of employees, the most represented are business entities with $0-4$ employees accounting for $48.4 \%$ of 
the total sample, followed by entities with $5-9$ employees with $40.3 \%$, entities with $10-49$ employees with $8.1 \%$, and entities with 250 and more employees with $3.2 \%$ of the total sample. No business entity has 50-249 employees.

The following table shows the duration of a business entity.

Table 4. The duration of a business entity

\begin{tabular}{|l|c|c|}
\hline Description & $\mathrm{N}$ & $\%$ \\
\hline Less than 5 years & 14 & $22.6 \%$ \\
\hline More than 5 years & 48 & $77.4 \%$ \\
\hline Total & 62 & $100.00 \%$ \\
\hline
\end{tabular}

Source: authors

Based on the analysis of the data from the previous table, it is evident that the largest number of examined business entities have existed for more than five years or $77.4 \%$ of the total number, while for businesses younger than 5 years the total amount is $22.6 \%$.

Based on the analysis of socio-demographic data, it can be concluded that the smallest business entities belong to accommodation and food service activities, from about 0 to 9 employees, while business entities which exist for more than five years were the most involved in the survey. After collecting the general information on business entities, the following portion of the questionnaire relates to organized risk management in entities.

The following table examines the existence of a person and/or a department dealing with the management of business and financial risks.

Table 5. Existence of a person and /or department business and financial risk management units

\begin{tabular}{|l|c|c|}
\hline Description & N & $\%$ \\
\hline Yes, person & 25 & $40.3 \%$ \\
\hline Yes, department & 0 & $0.0 \%$ \\
\hline No & 37 & $59.7 \%$ \\
\hline Total & 62 & $100.00 \%$ \\
\hline
\end{tabular}

Source: authors

Based on the conducted research on the existence of a person and/or department to manage business and financial risk, it is obvious that $59.7 \%$ of business entities neither have a person nor a business and financial risk management department. Of the total sample, $40.3 \%$ of business entities have a responsible person who manages business and financial risks. No business entity has a business and financial risk management department. The absence of any business entity that has a business and financial risk management department can be attributed to the size of the business entities surveyed, meaning that small business entities do not have sufficient revenue generated to support the setup of such departments, or their business and management process does not 
require that kind of organization. Based on the shown data it can be concluded that most of the business entities do not manage business and financial risks at all.

The upcoming table shows liquidity risk management in examined business entities.

Table 6. Liquidity risk management in a business entity

\begin{tabular}{|l|c|c|}
\hline Description & $\mathrm{N}$ & $\%$ \\
\hline Yes & 11 & $17.7 \%$ \\
\hline No & 43 & $69.3 \%$ \\
\hline I cannot estimate it & 8 & $13.0 \%$ \\
\hline Total & 62 & $100.00 \%$ \\
\hline
\end{tabular}

Source: authors

Similarly to the total management of business and financial risks, it is clear that very few business entities are managing liquidity risk. More precisely, out of $40.3 \%$ of business entities managing business and financial risks, only $17.7 \%$ manage liquidity risk.

Chart 1. Reasons for liquidity risk management in a business entity.

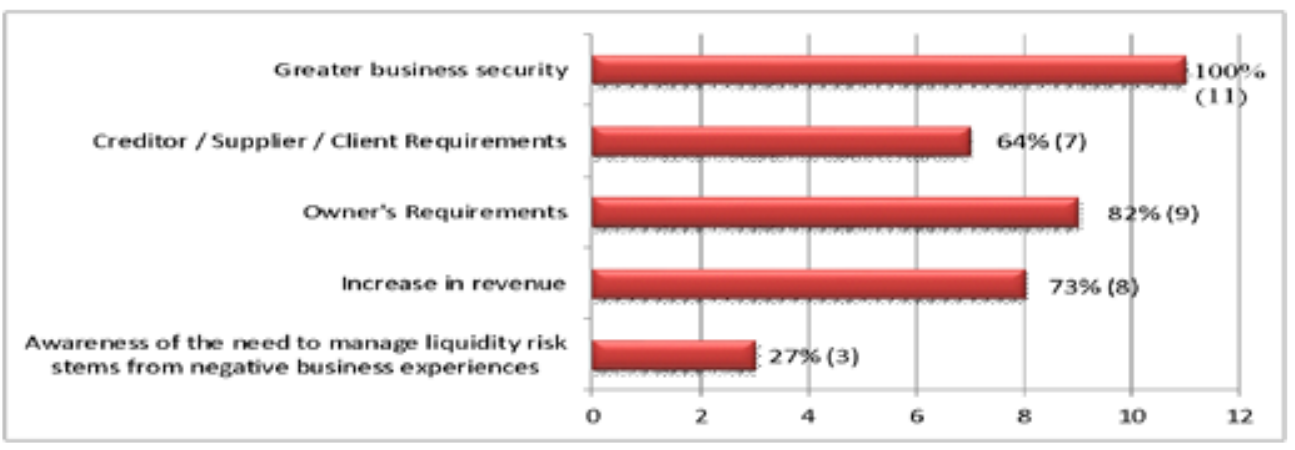

Source: authors

The analysis of this chart was not made on a sample of 62 business entities, but on a sample of 11 business entities which manage their liquidity risk in their business entity. Each of the percentages obtained in the graph represents the ratio between the total number of respondents who manage the liquidity risk and the respondents who claimed this was one of the reasons for managing the liquidity risk. It follows from the above that out of 11 of the respondents managing the liquidity risk, all 11 of them, or $100 \%$ stated that greater security of business was one of the reasons for liquidity risk management. Nine out of eleven (82\%) respondents stated that they manage liquidity risk due to owners' requests, $73 \%$ respondents claimed that they manage liquidity risk to increase revenue, $64 \%$ business entities manage liquidity risk because of credit/supplier/client requirements, and $27 \%$ of respondents as a reason cite awareness of the need to manage liquidity risk arising from negative business experiences. 


\section{1 Knowledge and use of indicators and methods of liquidity risk management in business entities in the Republic of Croatia}

The research conducted on the topic of the existence of business and financial risk management was followed by the examination of the knowledge and use of indicators and methods for liquidity risk management in business entities. The following table shows the knowledge of individual indicators and methods for liquidity risk management.

Table 7. Knowledge of indicators and methods of liquidity risk management

\begin{tabular}{|c|c|c|c|c|c|c|c|c|}
\hline \multirow[t]{2}{*}{$\begin{array}{l}\text { Indicators and methods of } \\
\text { liquidity risk management }\end{array}$} & \multicolumn{2}{|c|}{ YES } & \multicolumn{2}{|c|}{ NO } & \multicolumn{2}{|c|}{$\begin{array}{l}\text { I do not } \\
\text { know/l } \\
\text { cannot } \\
\text { evaluate }\end{array}$} & \multirow[t]{2}{*}{$(\%)$} & \multirow[t]{2}{*}{$\mathrm{N}$} \\
\hline & $\mathrm{N}$ & $(\%)$ & $\mathrm{N}$ & $(\%)$ & $\mathrm{N}$ & $(\%)$ & & \\
\hline Liquidity current ratio & 27 & $43.5 \%$ & 29 & $46.8 \%$ & 6 & $9.7 \%$ & $100 \%$ & 62 \\
\hline Liquidity quick ratio & 19 & $30.6 \%$ & 37 & $59.7 \%$ & 6 & $9.7 \%$ & $100 \%$ & 62 \\
\hline Liquidity cash ratio & 18 & $29 \%$ & 38 & $61.3 \%$ & 6 & $9.7 \%$ & $100 \%$ & 62 \\
\hline Financial stability coefficient & 9 & $14.5 \%$ & 47 & $75.8 \%$ & 6 & $9.7 \%$ & $100 \%$ & 62 \\
\hline Net working capital & 11 & $17.7 \%$ & 44 & $71 \%$ & 7 & 11.3 & $100 \%$ & 62 \\
\hline Cash Flow Ratio & 7 & $11.3 \%$ & 47 & $75.8 \%$ & 8 & $12.9 \%$ & $100 \%$ & 62 \\
\hline $\begin{array}{l}\text { Developing Liquidity } \\
\text { Management Plans }\end{array}$ & 7 & $11.3 \%$ & 55 & $88.7 \%$ & 0 & $0 \%$ & $100 \%$ & 62 \\
\hline $\begin{array}{l}\text { Diversification of Financing } \\
\text { Methods and Instruments }\end{array}$ & 49 & $79 \%$ & 10 & $16.1 \%$ & 3 & $4.9 \%$ & $100 \%$ & 62 \\
\hline $\begin{array}{l}\text { Holding a larger amount of } \\
\text { liquid assets in a business entity }\end{array}$ & 51 & $82.3 \%$ & 6 & $9.7 \%$ & 5 & $8 \%$ & $100 \%$ & 62 \\
\hline
\end{tabular}

Source: authors

From the available liquidity indicators, business entities answered that they are best acquainted with the liquidity current ratio, more precisely $43.5 \%$ of the respondents, while the liquidity method best known to business entities is the holding of a larger amount of liquid assets in the business entity, or $82.3 \%$. It could also be assumed that business entities would best know the liquidity current ratio, as this indicator measures the ability of a business entity to settle its shortterm liabilities. The least known liquidity management indicators are financial stability coefficient and cash flow ratio, where $75.8 \%$ business entities do not recognize these indicators. The least known method is developing liquidity management plans, given that $88.7 \%$ of respondents do not recognize this method. The results obtained show the levels of financial illiteracy of business entities in the Republic of Croatia, the result of which is the illiquidity of the entire market in the 
Republic of Croatia. According to the results of the survey of Benic and Franic, the Republic of Croatia belongs to countries with a higher level of illiquidity (2008: 481- 502).

The following table shows the use of indicators and methods for liquidity risk management in business entities.

Table 8. Use of indicators and methods of liquidity risk management in a business entity

\begin{tabular}{|l|c|c|c|c|c|c|c|c|}
\hline \multirow{2}{*}{$\begin{array}{l}\text { Indicators and methods of } \\
\text { liquidity risk management }\end{array}$} & \multicolumn{2}{|c|}{ YES } & \multicolumn{2}{|c|}{ NO } & \multicolumn{2}{|c|}{$\begin{array}{l}\text { I do not know/l } \\
\text { cannot evaluate }\end{array}$} & \multirow{2}{*}{ (\%) } & N \\
\cline { 2 - 9 } & $\mathrm{N}$ & $(\%)$ & $\mathrm{N}$ & $(\%)$ & $\mathrm{N}$ & $(\%)$ & & \\
\hline Liquidity current ratio & 13 & $21 \%$ & 41 & $66.1 \%$ & 8 & $12.9 \%$ & $100 \%$ & 62 \\
\hline Liquidity quick ratio & 9 & $14.5 \%$ & 45 & $72.6 \%$ & 8 & $12.9 \%$ & $100 \%$ & 62 \\
\hline Liquidity cash ratio & 11 & $17.7 \%$ & 45 & $72.6 \%$ & 6 & $9.7 \%$ & $100 \%$ & 62 \\
\hline $\begin{array}{l}\text { Financial stability } \\
\text { coefficient }\end{array}$ & 1 & $1.6 \%$ & 53 & $85.5 \%$ & 8 & $12.9 \%$ & $100 \%$ & 62 \\
\hline Net working capital & 7 & $11.3 \%$ & 48 & $77.4 \%$ & 7 & $11.3 \%$ & $100 \%$ & 62 \\
\hline Cash Flow Ratio & 1 & $1.6 \%$ & 52 & $83.9 \%$ & 9 & $14.5 \%$ & $100 \%$ & 62 \\
\hline $\begin{array}{l}\text { Developing Liquidity } \\
\text { Management Plans }\end{array}$ & 3 & $4.8 \%$ & 59 & $95.2 \%$ & 0 & $0 \%$ & $100 \%$ & 62 \\
\hline $\begin{array}{l}\text { Diversification of Financing } \\
\text { Methods and Instruments }\end{array}$ & 25 & $40.3 \%$ & 32 & $51.7 \%$ & 5 & $8 \%$ & $100 \%$ & 62 \\
\hline $\begin{array}{l}\text { Holding a larger amount of } \\
\text { liquid assets in a business } \\
\text { entity }\end{array}$ & 31 & $50 \%$ & 23 & $37.1 \%$ & 8 & $12.9 \%$ & $100 \%$ & 62 \\
\hline
\end{tabular}

Source: authors

Analyzing the use of indicators and methods for liquidity risk management in a business entity, it can be concluded that the liquidity current ratio is the most used indicator as it is used by $21 \%$ of the business entities surveyed, while holding a larger amount of liquid assets in a business entity is the most used method for managing liquidity risk, since $50 \%$ of business entities use this method. Such results are not surprising considering that business entities are the most familiar with the liquidity current ratio and the method of holding a larger amount of liquid assets in the business entity. Nor does it come as a surprise the finding that a very low number of business entities use the financial stability coefficient, that is $85.5 \%$ of respondents do not use this indicator in business. Fiftynine out of sixty-two (95.2\%) of business entities do not use the method of developing liquidity management plans, which is also not out of the ordinary since most of them are not familiar with the above method for liquidity risk management. These results are not unexpected because 
business entities, which do not acknowledge or are not aware of these indicators and methods, cannot subsequently use them in business. Due to insufficient financial education, business entities in the Republic of Croatia conduct business without financial plans so it is therefore not surprising that the Croatian market is illiquid.

\section{2 Valuation of liquidity risk in business es in the Republic of Croatia}

The ultimate aim of this research is to evaluate the importance of liquidity risk management in business operations. Below is a table showing the results of assessing the importance of liquidity risk management in business.

Table 9. The importance of liquidity risk management in business

\begin{tabular}{|l|c|c|}
\hline Managing Liquidity Risk in Business & Average & $\mathrm{N}$ \\
\hline Monitoring Liquidity Risk Indicators & 2.90 & 30 \\
\hline Reporting in a business entity about liquidity & 2.96 & 28 \\
\hline Monitoring liquidity impact on solvency & 3.00 & 27 \\
\hline Monitoring the impact of liquidity on profitability & 3.00 & 26 \\
\hline Use of methods for estimating and measuring liquidity risk & 2.64 & 33 \\
\hline $\begin{array}{l}\text { Current financial and accounting information in liquidity risk } \\
\text { management }\end{array}$ & 3.00 & 50 \\
\hline Influence of liquidity risk on other financial risks in a business entity & 3.00 & 28 \\
\hline
\end{tabular}

Source: authors

For this question, a three-point Likert scale was used to measure the respondents' opinion. The participants could evaluate each criterion with grades ranging from 1 - irrelevant, 2 - neither important nor unimportant, 3 - important, to 4 - cannot evaluate. By analyzing the results, it is apparent that the business entities are aware of the importance of monitoring the impact of liquidity on solvency, monitoring the impact of liquidity on profitability, monitoring of current financial accounting information and the impact of liquidity risk on other financial risks in the business entity in liquidity risk management, all of which are considered important for liquidity risk management. According to the importance of managing liquidity risk in business, the criteria that follow are reporting liquidity business with 2.96, then monitoring the liquidity risk indicators with 2.90 and using the methods for estimating and measuring the liquidity risk with 2.64. Consequently, it can be concluded that absolutely all of the listed criteria for managing liquidity risk in business are important for business entities. However, they do not know how to monitor important liquidity risk indicators and methods. This, again, points to inadequate financial education of business entities in Croatia. Therefore, it is necessary to invest more in the education of business entities at the level of the basic financial indicators which affect business entities on a daily basis and then at the level of the overall market of the Republic of Croatia. 


\section{CONCLUSION}

Business entities use different strategies and models for managing different risks to survive in a global, complex and unstable economic environment. Consequently, timely identification of all types of risks and adequate protection measures become an extremely important factor in business' success. In order to maintain the stability of their business and liquidity, business entities must incorporate risk management strategies into their strategic goals.

In the first part of the study, the organized management of business and financial risks in business entities was examined. Based on the obtained data, it can be concluded that most business entities do not manage business and financial risks by appointing a person responsible for them. It should be noted that small businesses were the most involved in the survey; therefore, a possible reason for not managing business and financial risks is certainly the inability to pay an additional person to manage business and financial risks because such a person would need to possess certain competencies and skills that entail a more expensive rate of pay. Thus, business and financial risks will be managed by business entities which understand the need for introducing individuals and/ or departments, but also those that can withstand such a cost, while financially weak business entities will operate without employees and/or departments. The liquidity risk is managed by only 11 business entities surveyed, or $17.7 \%$ of the total sample. Of the 62 surveyed businesses, 43 business entities, or $69.3 \%$, do not monitor liquidity risk. Similar to the issue of overall management of business and financial risks, it is evident that very few business entities are managing liquidity risk. This data may also be related to the fact that the surveyed business entities are aware of a very small percentage of indicators and methods of liquidity risk management.

The second part of the study analyzes the knowledge and use of indicators and methods for liquidity risk management in Croatian business entities. The results show that, of all the liquidity indicators, business entities are best acquainted with liquidity current ratio, namely $43.5 \%$, while the liquidity management method business entities are most aware of includes holding a larger amount of liquid assets in a business entity (82.3\%). Analyzing the use of indicators and methods for liquidity risk management in a business entity, it can be concluded that the current ratio is the most used indicator, as it is used by $21 \%$ of the business entities surveyed while holding a larger amount of liquid assets in the business entity is the most used method for liquidity risk management, employed by $50 \%$ of business entities. Such results are not surprising, since the liquidity current ratio and the method of holding a larger amount of liquid assets in the business entity have been identified as the most well-known indicators and methods of liquidity risk management for business entities. Nor is the finding that business entities use the financial stability coefficient the least surprising, as $85.5 \%$ of the respondents do not use this indicator at all. A large portion of business entities (95.2\%) do not use a method for developing liquidity management plans, which is also not surprising since most of them are not acquainted with the above method for liquidity risk management. Due to insufficient financial education, business entities in the Republic of Croatia do business without financial plans and then it should come as no surprise that the Croatian market is illiquid. The last part focuses on assessing the importance of risk management in business liquidity. All of the listed criteria for managing liquidity risk in business are important for business entities. However, the managers do not know how to monitor important liquidity risk 


\section{G. Karanović, B. Karanović, M. Gnjidić: Liquidity risk management: practice of Croatian firms Zbornik Veleučilišta u Rijeci, Vol. 6 (2018), No. 1, pp. 81-98}

indicators and methods. This, again, points to inadequate financial education of business entities in Croatia. Therefore, it is necessary to invest more in the education of business entities and their management at the level of the basic financial indicators, which affect business entities on a daily basis and then at the level of the overall market of the Republic of Croatia. Liquidity risk is the financial risk that needs to be managed because otherwise serious problems of illiquidity - and then potentially liquidation or bankruptcy of business entities - can arise. It is necessary, therefore, to establish a financial balance in each business entity, i.e. to tally the balance between assets with sources of assets.

\section{REFERENCES}

Acharya, V. V., Pedersen, L. H. (2005) "Asset pricing with liquidity risk", Journal of Financial Economics, Vol. 77, p. 375-410.

Amihud, Y., Mendelson, H. (1986) "Asset pricing and the bid ask spread”, Journal of Financial Economics, Vol. 17, p. 223-249

Amihud, Y., Mendelson H., Pedersen L. H. (2005) "Liquidity and Asset Prices," Foundations and Trends in Finance, Vol. 1 no. 4, p. 269-364.

Błach, J. et al. (2014) "Innovations in liquidity management - the potential of corporate treasury", Journal of Economics \& Management, Vol. 18. No. 14, p. 209-224.

Benic,V., Franic, I. (2008) „Komparativna analiza likvidnosti trzista kapitala Hrvatske i zemalja regije“, Financijska teorija i praksa, Vol.32, p. 481-502.

Benmelech, E., Bergman, N. K. (2009) “Collateral Pricing”, Journal of Financial Economics, Vol. 91., p. 339-360.

Berglof, E., Bolton, P. (2003) "The great divide and beyond - financial architecture in transition", The Journal of Economic Perspectives, Vol.16 No. 1. 16, 77-100.

Bangia, A. et al. (1999) "Modeling liquidity risk with implications for traditional market risk measurement and management", The Wharton Financial Institutions Center, p. 1-16.

Cizmesija, M., Kurnoga Zivadinovic, N. (2012) "Liquidity indicator for the Croatian economy - Factor analysis approach", Croatian Operational Research Review, 3(1), p. 280-288.

Cizmesija, M., Kurnoga, N., Bahovec, V. (2014) "Liquidity indicator for the Croatian economy - Factor analysis approach", Croatian Operational Research Review, 5(2), 305-316.

Crockett, A. (2008) “Market liquidity and Financial stability", Banque de France, Financial Stability Review, Special issue on liquidity, Vol. 11, p. 13-18.

Decman, N., (2012) „Financijski izvještaji kao podloga za ocjenu sigurnosti uspješnosti poslovanja malih i srednjih poduzeća u RH", Ekonomski pregled, Vol 63, No. (7-8), p. 446-467

Dencic-Mihajlov, K., Malinic, D., Grabinski, K. (2014) "Capital structure and liquidity during the financial crisis in Serbia: implications for the sustainability of the economy", Journal Post-Comunist Economies, Vol. 27. No. 1, p. 91-105.

Dumicic, K., et al. (2006). „Istraživanje primjene metoda upravljanja financijskim rizicima u hrvatskim poduzećima anketa na uzorku poduzeća", EFZG working paper series, 1-27.

Hadrovic Zekic, B. (2013) "Liquidity Ratios as Predictors of Organizational Decline: Evidence of The Eastern Croatia" in the Proceedings of $2^{\text {nd }}$ International Scientific Symposium Economy of Eastern Croatia - Yesterday, Today, Tomorrow, Osijek 23-25 $5^{\text {th }}$ May 2013., p. 44-56

Hiadlovsky, V., Rybovicova, I., Vinczeova, M. (2016) "Importance of liquidity analysis in the process of financial management of companies operating in the tourism sector in Slovakia: an empirical study, International Journal for Quality Research, Vol. 10, p. 799-811. 
Eriotis, N., Vasiliou, D., Ventoura-Neokosmidi, Z. (2007) “How firm characteristics affect capital structure: an empirical study", Managerial Fnance, Vol. 33, No. 5, p. 321-331.

FINA. (1. January 2017). www.fina.hr : http://www.fina.hr/. Download 2017 from www.fina.hr/Default.aspx?art=13013

Fink, G., Haiss, P. R., Vuksic, G. (2009) “Contribution of financial market segments at different stages of development: Transition, cohesion and mature economies compared", Journal of Financial Stability, vol. 5, no. 1431-455.

Jezovita., A. (2015) „Ocjena sigurnosti poslovanja poduzeca realnog sektora u Republici Hrvatskoj", Zbornik Ekonomskog fakulteta u Zagrebu, Vol. 13, 75-91.

Kim, C.S., Mauer, D.C., Sherman, A.E. (1998) "The determinants of corporate liquidity: theory and evidence, Journal of financial and quantitative analysis, Vol. 33, p. 335-359.

Kung'u, J. (2017) "Effect of Liquidity Management Practices on Profitability of Manufacturing Industry in Kenya", IOSR Journal of Economics and Finance, Vol. 8. No. 1, p. 84-89.

Lancaster, C., Stevens, J.L. (1998) "Corporate Liquidity and the Significance of Earnings Versus Cash Flow", The Journal of Applied Business Research, Vol. 14, No. 4, p. 27-38.

Lei, C. C., Lai, R. N. (2007) “The Role of Liquidity in Value at Risk: The Case of Hong Kong”, Working Paper. 20th Australasian Finance \& Banking Conference Paper.

Liu, Y., Ren, J., Zhuang, Y. (2009) "An empirical analysis on the capital structure of Chinese listed IT companies", International journal of business management, Vol. 4,No. 8, p. 46-51.

Lipson, M.L., Mortal, S. (2009) "Liquidity and capital structure", Journal of Financial Markets, Vol. 12, No. 4, p. 611-644.

Nikic, G. (2004) „Gospodarski aspekti pristupa Hrvatske Europskoj uniji: Proteklih deset godina i deset Godina ispred nas", Ekonomski pregled, Vol. 55, No 3-4, p. 197-226.

Mamic Sacer, I., Tusek, B., Korica, I. (2013) „Empirijska analiza utjecaja likvidnosti na profitabilnost hrvatskih srednjih i velikih poduzeca u grani djelatnosti informacije i komunikacije, Zbornik Ekonomskog fakulteta u Zagrebu, Vol. 11, $15-35$.

Mateev, M., Poutziouris, P., Ivanov, K. (2013) "On the determinants of SME capital structure in Central and Eastern Europe: a dynamic panel analysis", Research in international business and finance, Vol. 27, p. $28-51$.

Mihajlov, K. (2014) "Profitability during the Financial Crisis: Evidence from the Regulated Capital Market in Serbia“, SouthEastern Europe Journal of Economics, Vol. 1, p.7-33.

Minovic, J., Zivkovic, B. (2010) "Open Issues in Testing Liquidity in Frontier Financial Markets: The Case of Serbia“, Economic Annals, Vol. 55, no.185, p. 33-62.

Morallec, E. (2001) "Asset liquidity, capital structure, and secured debt", Journal of Fnancial Economics, Vol. 61 No. 2, p. 173-206.

Mushtaq. H., et.al. (2015) "Tradeoff between Liquidity and Profitability", International Journal of Scientific Research and Management, Vol. 3, No. 5, p. 2823-2842.

Olgic Drazenovic B, Kusanovic T., (2016) "Determinants of capital market in the new member EU countries", Economic Research-Ekonomska Istraživanja, Vol. 29, no. 1, 758-769, DOl:10.1080/1331677X.2016.1197551

Opler, T. et al. (1999) "The Determinants and Implications of Corporate Cash Holdings", Journal of Financial Economics, Vol. 52, p. 3-46.

Ortiz-Molina, H., Phillips, G.M. (2014) "Real Asset Illiquidity and the Cost of Capital",Journal of Financial and Quantitative Analysis, Vol. 49, p. 1-32.

Ozkan, A. (2001) “Determinants of capital structure and adjustment to long run target: evidence from UK company panel dana", Journal of Business Fnance and Accounting, Vol. 28, p. 175-198.

Rakesh Kumar, M. (2012) "Analysis of Liquidity Management and Trade Off Between Liquidity, Risk and Profitability at Garden Silk Mills Ltd: An Empirical Study, Journal of Commerce and Management Thought, Vol. 4, p. 118-132. 
Raykov, E. (2017) "The liquidity-profitability trade-off in Bulgaria in terms of the changed financial management functions during crisis",Management, Vol. 22, p. 135-156.

Sarlija, N. and Harc, M., (2012) "The impact of liquidity on the capital structure: a case study of Croatian firms" Business systems research, Vol. 3, No.1, p. 30-36.

Sarlija, N., Penavin, S., Harc, M. (2009) „Predviđanje nelikvidnosti poduzeca u Hrvatskoj“, Zbornik Ekonomskog fakulteta u Zagrebu, Vol. 7, p. 21-36.

Soric, I., (2004) „Likvidnost gospodarstva Splitsko-dalmatinske županije“, Ekonomski pregled Vol. 55., No 7-8., p. 557-579

Stange, S., Kaserer, C. (2011) “The Impact of Liquidity Risk: A Fresh Look”, International Review of Finance Vol. 11, No. 3, p. 269-301.

Suhaila, M., Wan, M., Wan, M. (2008) "Capital structure and firm characteristics: some evidence from Malaysian companies", MPRA paper 14616, Germany: University Library of Munich.

Tarnoczi, T., Fenyves, V. (2011) "Liquidity management and corporate risk", Annals of Faculty of Economics, Vol. 1, p. 530536.

Vieira, R. (2010) "An Exploratory Study of Airline Companies Between 2005 - 2008, Master Thesis, UMEA University, pp. 1-39. 


\section{UPRAVLJANJE RIZIKOM LIKVIDNOSTI: PRAKSA MEĐU HRVATSKIM TVRTKAMA ${ }^{4}$}

\section{SAŽETAK}

Glavna je surha rada istražiti praksu u upravljanju rizikom likvidnosti hrvatskih poslovnih entiteta. Analiza se temelji na istraživanju 62 poslovna entiteta u Hrvatskoj. Autori istražuju postojanje mjera upravljanja rizikom i upravljanja rizikom likvidnosti među anketiranim poslovnim entitetima. Menadžersko znanje sudionika, njihova uporaba indikatora i metoda za upravljanje rizikom likvidnosti zajedno s citiranim razlozima za uporabu mjera rizika likvidnosti također su istražene. Nadalje, autori su istražili važnost upravljanja likvidnosti u poslu. Analiza otkriva da hrvatski poslovni entiteti imaju nedovoljno znanje o većini financijskih indikatora te ne koriste planove upravljanja likvidnosti. S obzirom na to rezultati istraživanja ukazuju na neprimjerenu ukupnu razinu financijskog znanja hrvatskih menadžera. Dakle, to može biti identificirano kao jedan od razloga za tradicionalno velik broj nelikvidnih poslovnih entiteta na tržištu. Konačno, rad daje akademskim djelatnicima i političarima nova saznanja u vezi s upravljanjem rizikom likvidnosti među poslovnim entitetima u Hrvatskoj.

Ključne riječi: likvidnost, financije, upravljanje rizikom, Hrvatska, istraživanje

\footnotetext{
1 Dr. sc., docent, Fakultet za menadžment u turizmu i ugostiteljstvu, Primorska 42, 51410 Opatija, Hrvatska. E-mail: gorank@fthm.hr

2 Dr. sc., docent, Visoka poslovna škola PAR, Trg Riječke rezolucije 4, 51000 Rijeka, Hrvatska. E-mail: bisera.karanovic@par.hr

3 Mag. oec., studentica, Fakultet za menadžment u turizmu i ugostiteljstvu, Primorska 42, 51410 Opatija, Hrvatska. E-mail: martina.gnjidic@hotmail.com

4 Datum primitka rada: 13. 11. 2017.; datum prihvaćanja rada: 15. 1. 2018.
} 
